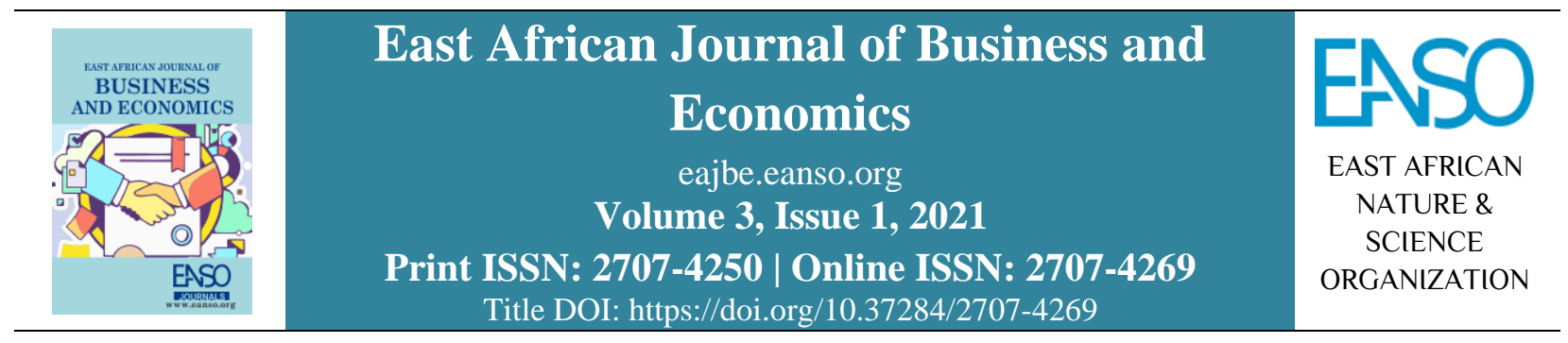

Original Article

\title{
Project Implementation, Risk Management Practices and Project Success
}

\author{
Joash Watema $^{1 *} \&$ John Tulirinya ${ }^{2}$ \\ ${ }^{1}$ College of Business and Management Sciences, Makerere University, P. O. Box 7062, Kampala, Uganda. \\ ${ }^{2}$ Department of Mathematics, Faculty of Science and Education, Busitema University, P. O. Box 236, Tororo, Uganda. \\ *Correspondence email: tulirinyajohn@gmail.com.
}

Article DOI: https://doi.org/10.37284/eajbe.3.1.296

\section{Date Published: ABSTRACT}

11 March 2021 The study aimed to establish the relationship between project implementation, risk management practices and project success for projects

Keywords: implemented by NGOs in Iganga Municipality. The study used a quantitative, correlational and cross-sectional survey design. The sample

Project Implementation, Risk Management Practices,

Project Success. consisted of 117 respondents who included project managers, their assistants, and accountants of 45 projects implemented by NGOs in Iganga Municipality. Data was collected using a self-administered questionnaire and analysed using statistical packages for social scientists (SPSS). This study discusses project implementation and risk management practices as the issues involved in project success and or failure. The study concluded that project implementation and risk management practices were significant in improving project success. This study recommended that NGOs in Iganga Municipality need to put much emphasis on project implementation and risk management practices as a way of improving project success as their correlation is significant.

\section{APA CITATION}

Watema, J., \& Tulirinya, J. (2021). Project Implementation, Risk Management Practices and Project Success. East African Journal of Business and Economics, 3(1), 36-50. https://doi.org/10.37284/eajbe.3.1.296

\section{CHICAGO CITATION}

Watema, Joash, and John Tulirinya. 2021. "Project Implementation, Risk Management Practices and Project Success". East African Journal of Business and Economics 3 (1), 36-50. https://doi.org/10.37284/eajbe.3.1.296.

\section{HARVARD CITATION}

Watema, J. and Tulirinya, J. (2021) "Project Implementation, Risk Management Practices and Project Success", East African Journal of Business and Economics, 3(1), pp. 36-50. doi: 10.37284/eajbe.3.1.296.

\section{IEEE CITATION}

J. Watema, and J. Tulirinya, "Project Implementation, Risk Management Practices and Project Success", EAJBE, vol. 3, no. 1, pp. 36-50, Dec. 2021. 


\section{MLA CITATION}

Watema, Joash, and John Tulirinya. "Project Implementation, Risk Management Practices and Project Success". East African Journal of Business and Economics, Vol. 3, no. 1, Mar. 2021, pp. 36-50, doi:10.37284/eajbe.3.1.296

\section{INTRODUCTION}

According to Adams and Barnd (1997), project success is the ability of the project to achieve its goals like time, cost, performance, quality, safety, and so on of the contractual parties established and put to test. Project success has been defined by the criteria of time, budget and deliverables (Atkinson, 1999). According to Baccarini (1999), a project is only successful if it comes on schedule, on budget, achieving the deliverables originally set for it as well as being acceptable and used by the clients for whom the project was intended. The completion criteria and satisfaction criteria are the core conditions for determining project success. If the project is well accepted by the users, the project is perceived to be successful (Kumaraswamy, 2006).

Juttner et al., (2003) emphasises that risk-taking of projects equals decision making under uncertainty and hence any strategic choice has certain risk implications and this explains why a project should embed risk management initiatives for its success. Jiang and Heiser (2004) contends that risk management is a structured approach to managing uncertainty related to a threat, through a sequence of human activities including: assessment, strategy development to managing it, and mitigation of risk using managerial resources.

In the implementation of community projects, Iganga Local Government works hand in hand with several partner NGOs that running different projects in the area. Plan International, one of the NGOs implementing community projects in Iganga designed several projects such as piped water, construction of office blocks for local government, extension of local government workers' houses and latrines (Plan International, 2014). However, according to the quarterly internal audit report (2013), the inspection of various Plan International projects in the different sub-counties in Iganga revealed that out of 24 work sites, $92 \%$ of the sites were incomplete while $8 \%$ were abandoned by the contractors without any explanation (Plan International, 2014). In addition, the report further revealed that out of 16 projects funded by the world bank under the School Facilitation Grants (SFGs) in secondary schools in Iganga, only $25 \%$ of the projects were finished, $50 \%$ were either abandoned or contracts terminated, $19 \%$ of the project sites with work on-going and $6 \%$ were yet to start. Plan International Audit report also revealed that the construction of office blocks, an extension of workers' houses, and latrines were implemented for an extra 2 years over the set period. In addition, the contract for the supply and installation of culverts in Iganga was awarded to a local company at a total cost of UGX 36,700,000. However, the actual payments to the contractor amounted to UGX. $42,058,500$ which included an overpayment of $14 \%$ (Plan International, 2014). Generally, projects implemented by NGOs in Iganga Municipality have low levels of success. This failure is associated with poor management of the implementation process (Cooke-Davis, 2002).

Despite efforts put in to ensure the success of projects, $50 \%$ of NGO projects succeed. $50 \%$ of projects implemented in Iganga Municipality were completed on time; those that were completed on time either were of good quality or did not have cost overruns and left the beneficiaries satisfied. In 2014 the National NGO forum, a renowned umbrella body for NGOs in Uganda reported that only $9 \%$ of the projects in large organisations were successful; this was attributed to projects not being completed as scheduled, having cost overruns and content deficiencies or not meeting the expectations of stakeholders (UNNGOF, 2015). Hence, this study sought to establish the relationship between Project Implementation, Risk Management Practices and Project Success of projects implemented by NGOs in Iganga Municipality. 


\section{LITERATURE REVIEW}

\section{Project Implementation}

Project implementation describes the strategy involved in preparing the end-users and the target product, service, or system into daily use or production (Jiang \& Heiser, 2004). The objective of the project implementation plan is to reduce the risk of implementation laid down by planning the impact to the business when the product, service, or system is implemented (Jiang \& Heiser, 2004). Factors that affect project implementation can be categorised as leadership style, information availability and accuracy, uncertainty, organisational structure, human resources, and technology. Lorange (2008) stated that human resources are becoming the key focus of project implementation and reiterated that people, not financial resources, are the key strategic resources in project implementation.

\section{Control}

Project management is the process of controlling the achievement of the project objectives, using the existing organisational structures and resources and manage the project by applying a collection of tools and techniques without interrupting the routine operation of a company (Bredillet, 2005). Some of the functions of project management are defining the work requirement, allocating resource needs, planning the execution of work required, monitoring the progress of the work and taking action to unexpected events that took place (Bredillet, 2005). Despite, projects are constrained by cost overrun, schedule, and technical performance objectives, project implementation is a connecting loop between formulation and control. Project control is also key in the determination of the relationship between project formulation and implementation. Turner (2005) investigated when it is best for organisations to think about project implementation: at the time of project formulation or afterward.

\section{Planning}

Project planning is concerned with establishing a predetermined course of action within a forecasted environment as postulated by Igwe and Ude (2018) who went on to argue that planning involves decision making that require choosing alternative courses of action to accomplish the project set objectives. Planning refers to the process of formulating scripts and potential action sequences that guide delivery (Mumford et al., 2015). Additionally, the planning process defines, activities, the time, cost and performance targets which aid the successful achievement of project objectives (Igwe \& Ude, 2018). Implementation planning includes planning functions that enable development of project implementation plans and comparison between the planned project objectives and the actual project performance (Marier Bienvenue et al., 2017).Risk Management Practices

According to Jiang and Heiser (2004), risk management is a structured approach to managing uncertainty related to a threat, through a sequence of human activities including: assessment, strategies development to manage it, and mitigation of risk using managerial resources. The strategies include transferring the risk to another party, avoiding the risk, reducing the negative effect of the risk, and accepting some or all of the consequences of a particular risk Jiang and Heiser (2004). Risk management plays an important role in maintaining project stability and efficiency throughout the project life cycle (Bin et al., 2013).

\section{Risk Identification}

According to Slevin and Pinto (1987), risk identification is the critical first step of the risk management process. Risk identification defines the set of events that could have an unwanted impact on the project's cost, schedule, or technical performance requirements. All project stakeholders have the responsibility to assist in the identification, validation, and eventual resolution of risk. Risks are identified and validated through systematic engineering analyses, as well as by the application of observation, judgment, and experience.

\section{Risk Assessment}

Risk assessment has a very important role before deploying a new technology or initiating any project. In order to discover the possible risks of a new technology deployment project, one has to understand how an appropriate basic risk assessment can be implemented. Risks should not 
only be assessed; it has to be well managed as well. It is not only important to know the risks but to find a solution for each possible (most probable) scenario; which is the key to managing risks and lowering the chance of project failure. Risk assessment is one of the two stages of the process that usually split into two 'sub-stages'; a qualitative investigation 'sub-stage' that focuses on identification and subjective estimation of risks and a quantitative assessment 'sub-stage' that focuses on an objective evaluation of the risks (Prabhakar, 2005). A qualitative assessment allows the main risk sources or factors to be identified. After the identification of the risk events, it has to be determined in what way they form a threat to the success of the project. The level of risk for each event has to be defined to rank the risks and to filter out the risk drivers for the project. Therefore, in the assessment process it is critical to make the besteducated guesses possible in order to properly prioritise the implementation of the risk management plan (Bredillet, 2014).

\section{Risk Monitoring}

Using metrics for project effectiveness, you must compare existing costs to project process costs after implementation. Metrics on quality and cost are necessary for measuring project effectiveness in making data more accessible and interchangeable.

\section{Project Success}

Project success refers to the completion of projects within the budgeted cost with basic criteria of cost, time and quality (Adams \& Barnd, 1997). The project is said to be successfully completed within the budgeted cost, implemented on time and to quality parameters requested. However, these criteria have received many critics for being inadequate in determining project success, customer opinion and contact was minimal and no long-term follow-up effort was established (Atkinson, 1999). The ability of the project team to implement and complete a project within a stipulated time frame is an attribute of project success (Blaskovics, 2014). All projects need to meet the specified time frame constraint for completion (Shenhar et al., 2001).

\section{Relationship between Project Implementation and Risk Management Practices}

Project implementation and risk management are positively related (Crawford et al., 2014). The purpose of addressing risk on projects is to help ensure project cost, schedule, and performance objectives are achieved at every stage in the life cycle and to communicate to all stakeholders the process for uncovering, determining the scope of, and managing program uncertainties (Krajewski \& Ritzman, 2005). Risk management is the overarching process that encompasses identification, assessment, mitigation planning, mitigation plan implementation, and tracking (Crawford et al., 2014). Risk management should begin at the earliest stages of project planning and continue throughout the total life-cycle of the program (Baccarini, 1999).

\section{Relationship between Risk Management Practices and Project Successes}

Risk Management and Project Successes are positively and significantly correlated, pursuant to project success; project risk must be identified, managed, and addressed throughout the project in order for the project to be successful (Belout, 1998). Risk management plays an important role in maintaining project stability and efficiency throughout the project life cycle (Belout, 1998). It proactively addresses potential obstacles that may arise and hinder project success and/or block the project team from achieving its goals. Munns and Bjeirmi (1996) claims that project management is an important part of project success. Duncan (2001) identified three problem areas that indicate the success of a project namely under-costing, overspending and late delivery.

\section{Relationship between Project Implementation and Project Success}

Atkinson (1999) asserts that for a project to be successful, management is recommended to implement its design strategies and controlling the achievement of the project objectives, using the existing organisational structures and resources and manage the project by applying a collection of tools and techniques without interrupting the routine operation of a company. Some of the functions of 
project implementation are defining the work requirement, allocating resource needs, planning the execution of work required, monitoring the progress of the work and taking action to unexpected events that took place (Munns \& Bjerimi, 1996).

\section{RESEARCH METHODOLOGY}

This study adopted a cross-sectional and quantitative approach. The study was correlational because its focus was to relate project implementation and risk management practices to project success and cross-sectional because the required data was collected from all respondents at once in order to minimise time and cost (Creswell, 2003). The population for the study was 55 NGO projects in Iganga municipality from which 48 NGO projects were sampled using Krejcie and Morgan (1970) table. Simple random sampling technique was used to sample the 48 projects. The unit of inquiry constituted of three project staff from each NGO; that was project manager, assistant project manager and project accountant who were purposively selected because were best suited to provide information on the NGOs. However, only 117 questionnaires were properly filled and returned and they are the ones the researcher used for data analysis. These were from 45 NGOs with 45 project managers, 32 assistant project managers and 40 project accountants responding.

A self-administered questionnaire was used to collect data from respondents. All variables were measured using a five-point liker scale, responses that are strongly disagree (1), disagree (2), neither agree nor disagree (3), agree (4) and strongly agree (5). Project implementation was measured to include three dimensions; planning, operation and control. Risk Management practices was measured to include four dimensions; Risk Identification, Risk Monitoring, Risk assessment and risk response. Project success was measured to include four dimensions; timeliness, stakeholder satisfaction, cost effectiveness, and quality. Collected data was analyzed using a Statistical Package for Social Scientist (SPSS) version 20.0. Descriptive and inferential analysis of measurable relationships between the study variables was extracted. Factor determination was done for consequent analysis. In addition, Pearson`s correlation analysis was used for associations and predictor contributions respectively and a regression analysis was also used to determine the predictive power of the dependent variable on the independent variables.

\section{RESULTS AND DISCUSSIONS}

\section{Project Implementation}

Descriptive statistics in Table 1 below were presented from a questionnaire that was coded such that $1=$ Strongly Disagree, $2=$ Disagree, $3=$ Neither agree nor disagree, $4=$ Agree and $5=$ Strongly Agree. The data was interpreted such that means that are close to 1 or 2 reflect Disagreement while those means that are close to 4 or 5 indicate agreement and means that are close to 3 show uncertainty with the issue at hand. Project implementation was conceptualised as planning, operations and control that each had subscales as shown in Table 1 below. Table 1 also shows corresponding minimum values, maximum values, means and standard deviation regarding respondents rating of project implementation.

\section{Table 1: Showing project implementation}

\begin{tabular}{|c|c|c|c|c|c|}
\hline Content & $\mathbf{N}$ & Min & Max & Mean & SD \\
\hline We develop plans for project implementation & 117 & 1.00 & 5.00 & 4.41 & .842 \\
\hline Our implementation plans are well funded & 117 & 1.00 & 5.00 & 3.71 & 1.067 \\
\hline $\begin{array}{l}\text { Our implementation plans are well communicated to the relevant } \\
\text { stakeholders }\end{array}$ & 117 & 1.00 & 5.00 & 4.11 & 1.015 \\
\hline There are planned resources for projects & 117 & 1.00 & 5.00 & 3.91 & .991 \\
\hline We follow our implementation plan & 117 & 1.00 & 5.00 & 4.14 & .982 \\
\hline Planning & & & & 4.05 & .762 \\
\hline We have enough trained personnel to implement our projects & 117 & 1.00 & 5.00 & 3.75 & 1.181 \\
\hline $\begin{array}{l}\text { There is interaction of project staff during project implementation in our } \\
\text { organisation }\end{array}$ & 117 & 1.00 & 5.00 & 4.09 & 1.017 \\
\hline
\end{tabular}




\begin{tabular}{llllll}
\hline Content & N & Min & Max & Mean & SD \\
\hline $\begin{array}{l}\text { Our project implementation involves working hand in hand with partners and } \\
\text { other NGOs }\end{array}$ & 117 & 1.00 & 5.00 & 4.26 & .865 \\
Project implementation funds are remitted timely to respective users & 117 & 1.00 & 5.00 & 3.51 & 1.072 \\
Projects are implemented as scheduled; on time & 117 & 1.00 & 5.00 & 3.83 & .985 \\
Operation & & & & 3.89 & .793 \\
Management is committed to the operations of the NGO & 117 & 1.00 & 5.00 & 4.09 & .974 \\
There are clear set targets to be attained & 117 & 1.00 & 5.00 & 4.32 & .906 \\
Management evaluates the progress of the projects in this NGO & 117 & 1.00 & 5.00 & 4.12 & .975 \\
There is appropriate supervision by senior staff on the work of the juniors & 117 & 1.00 & 5.00 & 4.32 & .818 \\
Communication is done timely to guide implementation of projects & 117 & 1.00 & 5.00 & 4.09 & .947 \\
There is timely feedback about project implementation progress & 117 & 1.00 & 5.00 & 3.92 & .939 \\
We involve people through motivating reward system when implementing & 117 & 1.00 & 5.00 & 3.61 & 1.025 \\
projects & & & & & \\
There are clear quality guidelines and principles & 117 & 1.00 & 5.00 & 3.89 & 1.120 \\
Control & & & & $\mathbf{4 . 0 5}$ & $\mathbf{. 7 4 6}$ \\
Global variable characteristics & & & & $\mathbf{4 . 0 0}$ & $\mathbf{. 6 9 0}$ \\
\hline
\end{tabular}

Study findings show an average value of 4.00, which indicates that NGOs in Iganga Municipality agree with the significance of project implementation for their projects. The answers to the eighteen statements about project implementation indicate that NGOs in Iganga Municipality still have to understand and manage the implementation process of projects. Table 1 also indicates the relative importance of each statement; the first statement obtained the highest mean value of 4.41 implying that NGOs in Iganga Municipality appreciate the need for project planning. The lowest mean is 3.51 for the ninth statement, indicating that project implementation funds are not remitted on time. The global standard deviation is 0.690 suggesting that the data points are not far from the mean value of 4.00. This means suggested that generally, the respondents agreed with the need for proper project implementation.

\section{Risk Management Practices}

Project risk management practices were conceptualised as identification, monitoring, assessment and response that each had subscales as shown in Table 2 below. Table 2 shows an average value of 3.59, which indicates that NGOs in Iganga Municipality appreciate the need for good risk management practices. The answers to the twenty statements about risk management practices indicate that NGOs in Iganga Municipality still have to understand and manage risks associated with projects. This means suggested that generally, the respondents agreed with the need for risk management of projects. Table 2 also indicates the relative importance of each statement; the third statement obtained the highest mean value of 4.05 implying that NGOs in Iganga Municipality have clear procedures for management of project works. The lowest mean is 3.31 for the tenth statement, indicating that risk identification is not carried out. In general, the results showed a global standard deviation is 0.764 , meaning that the data points are not far from the mean value of 3.59. This means suggested that generally, the respondents agreed with the need for risk management of projects.

\section{Table 2: Risk management practices}

\begin{tabular}{|c|c|c|c|c|c|}
\hline Content & $\mathbf{N}$ & Min & Max & Mean & SD \\
\hline Our NGO carries out risk identification relating to the declared objectives & 117 & 1.00 & 5.00 & 3.59 & 1.108 \\
\hline We carry out prefeasibility studies of projects & 117 & 1.00 & 5.00 & 3.73 & 1.056 \\
\hline There are separate procedures for the management of project works & 117 & 2.00 & 5.00 & 4.05 & .818 \\
\hline $\begin{array}{l}\text { Changes in risks are recognised with the NGO project rules and } \\
\text { responsibilities }\end{array}$ & 117 & 1.00 & 5.00 & 3.84 & .991 \\
\hline We use techniques in identifying risks & 117 & 2.00 & 5.00 & 3.84 & .880 \\
\hline Identification & & & & 3.81 & .721 \\
\hline
\end{tabular}




\begin{tabular}{|c|c|c|c|c|c|}
\hline Content & $\mathbf{N}$ & Min & Max & Mean & SD \\
\hline We monitor identified risks to minimise their impact & 117 & 1.00 & 5.00 & 3.79 & 1.002 \\
\hline We involve all stakeholders in risk monitoring & 117 & 1.00 & 5.00 & 3.61 & 1.144 \\
\hline $\begin{array}{l}\text { Monitoring the efficiency of risk management is an integral part of routine } \\
\text { management reporting }\end{array}$ & 117 & 1.00 & 5.00 & 3.74 & 1.086 \\
\hline $\begin{array}{l}\text { Risk monitoring covers the evaluation of the effectiveness and efficiency of } \\
\text { the NGO in achieving set objectives }\end{array}$ & 117 & 1.00 & 5.00 & 3.73 & 1.127 \\
\hline We have in place risk management procedures & 117 & 1.00 & 5.00 & 3.31 & 1.200 \\
\hline $\begin{array}{l}\text { The NGO is aware of the strengths and weaknesses of its risk management } \\
\text { system }\end{array}$ & 117 & 1.00 & 5.00 & 3.51 & 1.193 \\
\hline Monitoring & & & & 3.61 & .903 \\
\hline $\begin{array}{l}\text { The NGO has designed a system to measure appropriately the impact of the } \\
\text { risk }\end{array}$ & 117 & 1.00 & 5.00 & 3.30 & 1.308 \\
\hline $\begin{array}{l}\text { The NGO analyses and evaluates the opportunities that it has to achieve } \\
\text { objectives }\end{array}$ & 117 & 1.00 & 5.00 & 3.59 & 1.161 \\
\hline Our NGO assesses the likelihood of occurring risk on a timely basis & 117 & 1.00 & 5.00 & 3.41 & 1.131 \\
\hline There is a board concerned with the evaluation of the risks of the projects & 117 & 1.00 & 5.00 & 3.44 & 1.262 \\
\hline The NGO has proper risk assessment procedure in place & 117 & 1.00 & 5.00 & 3.44 & 1.296 \\
\hline $\begin{array}{l}\text { Our NGO is aware of the strengths and weaknesses of its management } \\
\text { systems of the projects }\end{array}$ & 117 & 1.00 & 5.00 & 3.58 & 1.044 \\
\hline Assessment & & & & 3.46 & 1.022 \\
\hline We design clear mitigation & 117 & 1.00 & 5.00 & 3.49 & 1.014 \\
\hline Our $r$ & 117 & 1.00 & 5.00 & 3.47 & 1.087 \\
\hline Our responses to risks include & 117 & 1.00 & 5.00 & 3.32 & 1.128 \\
\hline Our response to risks is effectively implemented & 117 & 1.00 & 5.00 & 3.45 & 1.021 \\
\hline The project responds to risks are cost-effective & 117 & 1.00 & 5.00 & 3.45 & 1.021 \\
\hline $\begin{array}{l}\text { The NGOs response to analyse risks includes prioritising risks and selecting } \\
\text { those that need active management }\end{array}$ & 117 & 1.00 & 5.00 & 3.79 & .908 \\
\hline $\begin{array}{l}\text { The NGOs response to risks includes action plans for implementing } \\
\text { decisions about identified risk }\end{array}$ & 117 & 1.00 & 5.00 & 3.70 & .976 \\
\hline Response & & & & 3.46 & 1.022 \\
\hline Global variable characteristics & & & & 3.59 & .764 \\
\hline
\end{tabular}

\section{Project Success}

Project success was conceptualised as timeliness, stakeholder satisfaction, cost-effectiveness and quality that each had subscales as shown in Table 3 below. Table 3 shows an average value of 4.00, which indicates that NGOs in Iganga Municipality are mindful of the success of their projects. The answers to the twenty-one questions about project success indicate that NGOs in Iganga Municipality still have to understand the success of their projects.
The mean suggested that generally, the respondents agreed with project success as a measure of performance. Table 3 also indicates the relative importance of each statement; the eighth statement obtained the highest mean value of 4.30 implying that NGOs in Iganga Municipality had their financial reports prepared on time. The lowest mean is 3.62 for the twenty-first statement, indicating that risks were not alleviated timely. The global standard deviation was 0.617 , meaning that the data points are not far from the mean.

\section{Table 3: Project success}

\begin{tabular}{|c|c|c|c|c|c|}
\hline Content & $\mathbf{N}$ & Min & Max & Mean & SD \\
\hline $\begin{array}{l}\text { Accountability for funds allocated for the implementation of the project is } \\
\text { done on time }\end{array}$ & 117 & 1.00 & 5.00 & 3.98 & 1.114 \\
\hline Our projects are implemented on time & 117 & 1.00 & 5.00 & 3.95 & 1.024 \\
\hline The financial reports of the $\mathrm{NGO}$ are timely prepared & 117 & 1.00 & 5.00 & 4.07 & 1.015 \\
\hline Project objectives are ac & 117 & 1.00 & 5.00 & 3.80 & 1.036 \\
\hline Risks are timely alleviated which leads to project success & 117 & 1.00 & 5.00 & 3.79 & .979 \\
\hline
\end{tabular}




\begin{tabular}{|c|c|c|c|c|c|}
\hline Content & $\mathbf{N}$ & Min & Max & Mean & SD \\
\hline Timeliness & & & & 3.92 & .835 \\
\hline Our stakeholders are satisfied with the NGO projects & 117 & 1.00 & 5.00 & 4.07 & .944 \\
\hline The information that is presented by this NGO is accurate & 117 & 1.00 & 5.00 & 4.21 & .899 \\
\hline There are policies, guidelines and procedures governing this NGO & 117 & 1.00 & 5.00 & 4.30 & .864 \\
\hline $\begin{array}{l}\text { There are guarantees of this NGO that the implemented projects are } \\
\text { successful }\end{array}$ & 117 & 1.00 & 5.00 & 4.09 & 1.106 \\
\hline This NGO gives extensiveness and intensity service to all its beneficiaries & 117 & 1.00 & 5.00 & 3.90 & 1.045 \\
\hline Stakeholder satisfaction & & & & 4.11 & .795 \\
\hline Cost-effectiveness and cost-benefit are conducted in this NGO & 117 & 1.00 & 5.00 & 3.84 & 1.008 \\
\hline $\begin{array}{l}\text { A general financial assessment of the project is presented with an } \\
\text { indication of the affordability of the project }\end{array}$ & 117 & 1.00 & 5.00 & 3.97 & .880 \\
\hline A system of accounting tables is prepared for each project & 117 & 1.00 & 5.00 & 3.99 & 1.126 \\
\hline $\begin{array}{l}\text { The economic maturity of project documentation and affordability is } \\
\text { prepared }\end{array}$ & 117 & 2.00 & 5.00 & 3.96 & .835 \\
\hline There is project management set up and reporting lines in our NGO & 117 & 1.00 & 5.00 & 4.00 & .910 \\
\hline Our projects are affected by cost overruns & 117 & 1.00 & 5.00 & 3.85 & .997 \\
\hline Cost-effectiveness & & & & 3.93 & .646 \\
\hline Our officers concerned with project success are highly skilled & 117 & 1.00 & 5.00 & 4.14 & .991 \\
\hline Our NGO to a greater extent depends on donor funds for their o & 117 & 1.00 & 5.00 & 4.18 & 1.103 \\
\hline $\begin{array}{l}\text { The managers concerned with the provision of the project financial reports } \\
\text { are reliable and committed to their work }\end{array}$ & 117 & 1.00 & 5.00 & 4.17 & .922 \\
\hline The project reports provided to users are easily understood & 117 & 1.00 & 5.00 & 4.16 & .871 \\
\hline There are situations of over expenditure on some project activities & 117 & 1.00 & 5.00 & 3.62 & 1.216 \\
\hline Quality & & & & 4.05 & .622 \\
\hline Project success & & & & 4.00 & .617 \\
\hline
\end{tabular}

\section{Factor Analysis}

Factor analysis is a means by which the regularity and order in phenomena can be discerned. Factor analysis can be applied in order to explore a content area, structure a domain, map unknown concepts, classify or reduce data, illuminate causal nexuses, screen or transform data, define relationships, test hypotheses, formulate theories, control variables, or make inferences (Ahmavaara \& Tourco 1958). Factor analysis was done because it enabled the researcher to investigate concepts that are not easily measured directly by collapsing a large number of variables into a few interpretable underlying factors. While trying to understand the factors in project implementation, risk management practices and project success, factor analysis was carried out. All primary data from study variables underwent principal component analysis for factor loading using varimax rotation with Kaiser Normalization method for easy interpretation. All factor rotations were converged in two iterations. The results of factor analysis of the variables; project implementation, risk management practices and project success are indicated in Tables 4, 5 and 6 below.

\section{Project Implementation}

Factor analysis yielded three components which were interpreted as Planning (var $=50.007 \%$ ), operation (var $=8.238 \%)$ and control (var $=$ $6.209 \%$ ), explaining project implementation variance of $64.519 \%$ (Table 4). Five item scales were loaded on the Planning component. The item with the highest loading was "we follow our implementation plan" (0.878) and "our implementation plans are well funded" $(0.749)$ had the least loading. The operation component was loaded five subcomponents from which the item "Project implementation funds are remitted timely to the respective users" had the highest loading of 0.814 while item "We have enough trained personnel to implement projects" had the least loading of 0.719. In addition, the control component was loaded with eight scales from which item "Management is committed to the operations of the NGO" had the highest loading of 0.850 while item "We involve people through motivating reward system when implementing projects" had the least loading of 0.656 (Table 4). 
East African Journal of Business and Economics, Volume 3, Issue 1, 2021

Article DOI: https://doi.org/10.37284/eajbe.3.1.296

Table 4: Factor analysis for project implementation

\begin{tabular}{|c|c|c|c|}
\hline \multirow[t]{2}{*}{ Project Implementation } & \multicolumn{3}{|c|}{ Components } \\
\hline & Planning & Operation & Control \\
\hline We develop plans for project implementation & 0.697 & & \\
\hline Our implementation plans are well funded & 0.749 & & \\
\hline Our implementations plan are communicated to the relevant stakeholders & 0.763 & & \\
\hline There are planned resources for the project & 0.793 & & \\
\hline We follow our implementation plan & 0.878 & & \\
\hline We have enough trained personnel to implement projects & & 0.719 & \\
\hline $\begin{array}{l}\text { There is interaction of project staff during the project implementation in } \\
\text { our NGO }\end{array}$ & & 0.808 & \\
\hline $\begin{array}{l}\text { Our project implementation involves working hand in hand with partners } \\
\text { and several NGOs }\end{array}$ & & 0.75 & \\
\hline Project implementation funds are remitted timely to the respective users & & 0.814 & \\
\hline Projects are implemented on time as scheduled & & 0.784 & \\
\hline Management is committed to the operations of the NGO & & & 0.85 \\
\hline There are clear output or set targets to be attained & & & 0.782 \\
\hline Management evaluates the progress of projects in this NGO & & & 0.784 \\
\hline $\begin{array}{l}\text { There is appropriate supervision by senior staff on the work of their } \\
\text { juniors }\end{array}$ & & & 0.795 \\
\hline $\begin{array}{l}\text { Communication is timely done to guide the implementation of the project } \\
\text { in this NGO }\end{array}$ & & & 0.784 \\
\hline There is timely feedback about project implementation progress & & & 0.77 \\
\hline $\begin{array}{l}\text { We involve people through motivating reward system when implementing } \\
\text { projects }\end{array}$ & & & 0.656 \\
\hline There are clear quality guidelines and principles & & & 0.778 \\
\hline Eigen Values & 9.014 & 1.482 & 1.118 \\
\hline Percentage of variance & 50.007 & 8.238 & 6.209 \\
\hline Cumulative percentage & 50.007 & 58.311 & 64.519 \\
\hline
\end{tabular}

\section{Risk Management Practices}

Factor analysis yielded four components which were interpreted as identification ( $\operatorname{var}=49.918 \%)$, monitoring ( $\mathrm{var}=8.880 \%)$, assessment $(\mathrm{var}=$ $6.345 \%$ ) and response (var $=5.050 \%)$, explaining risk management variance of $70.193 \%$. Five item scales were loaded on the identification component. The item with the highest loading was "Our NGO carries out comprehensive identification of risks" $(0.800)$ and "We use various techniques in identifying risks" $(0.749)$ had the least loading. The monitoring component was loaded six-item scales from which item "Risk monitoring covers the evaluation of the effectiveness and efficiency of the NGO in achieving set objectives" had the highest loading of 0.883 (Table 5). While item "We involve all stakeholders in risk monitoring for effective monitoring" had the least loading of 0.665 . The assessment component had six-item scales from which item "The NGO has proper risk assessment procedures in place" had the highest load of 0.896 while item "The NGO analyses and evaluates the opportunities that it has to achieve objectives" had the least load of 0.810 (Table 5). In addition, the response component was loaded with seven scales from which item "Our response to risk include an assessment of costs and benefits" had the highest loading of 0.861 while item "The NGO's risk response includes prioritising risks and selecting those that need active management" had the least loading of 0.716 (Table 5). 
Table 5: Factor analysis for risk management practices

\begin{tabular}{|c|c|c|c|c|}
\hline \multirow[t]{2}{*}{ Risk management practices } & \multicolumn{4}{|c|}{ Components } \\
\hline & $\begin{array}{l}\text { Identific } \\
\text { ation }\end{array}$ & $\begin{array}{l}\text { Monito } \\
\text { ring }\end{array}$ & $\begin{array}{l}\text { Assess } \\
\text { ment }\end{array}$ & $\begin{array}{l}\text { Resp } \\
\text { onse }\end{array}$ \\
\hline Our NGO carries out comprehensive identification of risks & 0.8 & & & \\
\hline We carry out pre-feasibility studies of projects & 0.671 & & & \\
\hline $\begin{array}{l}\text { There are separate procedures for the management of project } \\
\text { works }\end{array}$ & 0.753 & & & \\
\hline $\begin{array}{l}\text { Changes in risk are recognised and identified with the NGO's } \\
\text { rules and responsibilities }\end{array}$ & 0.787 & & & \\
\hline We use various techniques in identifying risks & 0.695 & & & \\
\hline We monitor identified risks to minimise their impact & & 0.751 & & \\
\hline $\begin{array}{l}\text { We involve all stakeholders in risk monitoring for effective } \\
\text { monitoring }\end{array}$ & & 0.665 & & \\
\hline $\begin{array}{l}\text { Monitoring the efficiency of risk management is an integral } \\
\text { part of routine management reporting }\end{array}$ & & 0.858 & & \\
\hline $\begin{array}{l}\text { Risk monitoring covers the evaluation of the effectiveness and } \\
\text { efficiency of the NGO in achieving set objectives }\end{array}$ & & 0.883 & & \\
\hline We have in place risk management procedures & & 0.842 & & \\
\hline $\begin{array}{l}\text { The NGO is aware of the strength and weaknesses of its risk } \\
\text { management systems }\end{array}$ & & 0.797 & & \\
\hline $\begin{array}{l}\text { The NGO has designed a system to measure appropriately the } \\
\text { impact of the risks }\end{array}$ & & & 0.855 & \\
\hline $\begin{array}{l}\text { The NGO analyses and evaluates the opportunities that it has } \\
\text { to achieve objectives }\end{array}$ & & & 0.81 & \\
\hline $\begin{array}{l}\text { Our NGO assesses the likelihood of occurring risk on a timely } \\
\text { basis }\end{array}$ & & & 0.862 & \\
\hline There is a board concerned with the evaluation of project risks & & & 0.858 & \\
\hline The NGO has proper risk assessment procedures in place & & & 0.896 & \\
\hline We assess risks using appropriate qualitative analysis methods & & & 0.818 & \\
\hline We design clear mitigation responses & & & & 0.797 \\
\hline Our risk responses are clearly communicated & & & & 0.842 \\
\hline $\begin{array}{l}\text { Our response to risk includes an assessment of costs and } \\
\text { benefits }\end{array}$ & & & & 0.861 \\
\hline Our response to risks is effectively implemented & & & & 0.788 \\
\hline The project risk responses are cost-effective & & & & 0.789 \\
\hline $\begin{array}{l}\text { The NGO's risk response includes prioritising risks and } \\
\text { selecting those that need active management }\end{array}$ & & & & 0.716 \\
\hline $\begin{array}{l}\text { The NGO's response to risks includes action plans for } \\
\text { implementing decisions about identified risks }\end{array}$ & & & & 0.743 \\
\hline Eigen Values & 11.98 & 2.131 & 1.523 & 1.212 \\
\hline Percentage of variance & 49.918 & 8.88 & 6.345 & 5.05 \\
\hline Cumulative percentage & 49.918 & 58.798 & 65.143 & $\begin{array}{l}70.19 \\
3\end{array}$ \\
\hline $\begin{array}{l}\text { Extraction Method: Principal Component Analysis. } \\
\text { Normalization. a. Rotation converged in } 10 \text { iterations. }\end{array}$ & & & $x$ & Kaiser \\
\hline
\end{tabular}




\section{Project Success}

Factor analysis yielded four components which were interpreted as timeliness ( $\operatorname{var}=42.716 \%)$, stakeholder satisfaction (var $=13.774 \%)$, costeffectiveness $(\mathrm{var}=10.233 \%)$ and quality $(\mathrm{var}=$ $4.769 \%$ ), explaining project success variance of $71.492 \%$ (Table 6). Five item scales were loaded on the timeliness component. The item with the highest loading was "Our projects are implemented on time" (0.879) and "The financial reports of the NGO are timely prepared" $(0.800)$ had the least loading (Table 6). The stakeholder satisfaction component was loaded five sub-components from which item "The information that is presented by this NGO is accurate" had the highest loading of 0.859 while item "There are guarantees of this NGO that the implemented projects are successful" had the least loading of 0.724 . The cost-effectiveness component had six sub-components from which item "Our projects are affected by cost overruns" had the highest load of 0.949 while item "There is project management set up and reporting lines in our NGO" had the least load of 0.624 (Table 6). In addition, the quality component was loaded with five scales from which item "There are situations of over expenditure on some project activities" had the highest loading of 0.965 while item "The managers concerned with the provision of the project financial reports are reliable and committed to their jobs" had the least loading of 0.664 (Table 6).

\section{Table 6: Factor analysis for project success}

\begin{tabular}{|c|c|c|c|c|}
\hline \multirow[t]{2}{*}{ Project success } & \multicolumn{4}{|c|}{ Components } \\
\hline & $\begin{array}{l}\text { Timel } \\
\text { iness }\end{array}$ & $\begin{array}{l}\text { Stakeholder } \\
\text { Satisfaction }\end{array}$ & $\begin{array}{l}\text { Cost- } \\
\text { effectiven } \\
\text { ess }\end{array}$ & $\begin{array}{l}\text { Qu } \\
\text { alit } \\
\text { y }\end{array}$ \\
\hline $\begin{array}{l}\text { Accountability for funds allocated for the implementation of the } \\
\text { project is done on time }\end{array}$ & 0.824 & & & \\
\hline Our projects are implemented on time & 0.879 & & & \\
\hline The financial reports of the NGO are timely prepared & 0.8 & & & \\
\hline Project objectives are achieved on time & 0.834 & & & \\
\hline Risks are timely alleviated which leads to project success & 0.697 & & & \\
\hline Our stakeholders are satisfied with the NGO projects & & 0.84 & & \\
\hline The information that is presented by this NGO is accurate & & 0.859 & & \\
\hline There are policies, guidelines and procedures governing this NGO & & 0.856 & & \\
\hline $\begin{array}{l}\text { There are guarantees of this NGO that the implemented projects } \\
\text { are successful }\end{array}$ & & 0.724 & & \\
\hline $\begin{array}{l}\text { This NGO gives Extensiveness and intensity service to all its } \\
\text { beneficiaries }\end{array}$ & & 0.822 & & \\
\hline Cost-effectiveness and cost-benefit are conducted in this NGO & & & 0.788 & \\
\hline $\begin{array}{l}\text { A general financial assessment of the project is presented with an } \\
\text { indication of the affordability of the project }\end{array}$ & & & 0.84 & \\
\hline A system of accounting tables is prepared for the project & & & 0.852 & \\
\hline $\begin{array}{l}\text { The economic maturity of project documentation and affordability } \\
\text { is prepared }\end{array}$ & & & 0.712 & \\
\hline There is project management set up and reporting lines in our NGO & & & 0.624 & \\
\hline Our projects are affected by cost overruns & & & 0.949 & \\
\hline Our officers concerned with project success are highly skilled & & & & $\begin{array}{l}0.67 \\
9\end{array}$ \\
\hline $\begin{array}{l}\text { Our NGO to a greater extent depends on donor funds for their } \\
\text { operation }\end{array}$ & & & & $\begin{array}{l}0.70 \\
5\end{array}$ \\
\hline $\begin{array}{l}\text { The managers concerned with the provision of the project financial } \\
\text { reports are reliable and committed to their jobs }\end{array}$ & & & & $\begin{array}{l}0.66 \\
4\end{array}$ \\
\hline The project reports provided to users are easily understood & & & & $\begin{array}{l}0.79 \\
4\end{array}$ \\
\hline There are situations of over expenditure on some project activities & & & & $\begin{array}{l}0.96 \\
5\end{array}$ \\
\hline
\end{tabular}


East African Journal of Business and Economics, Volume 3, Issue 1, 2021

Article DOI: https://doi.org/10.37284/eajbe.3.1.296

\begin{tabular}{|c|c|c|c|c|}
\hline \multirow[t]{2}{*}{ Project success } & \multicolumn{4}{|c|}{ Components } \\
\hline & $\begin{array}{l}\text { Timel } \\
\text { iness }\end{array}$ & $\begin{array}{l}\text { Stakeholder } \\
\text { Satisfaction }\end{array}$ & $\begin{array}{l}\text { Cost- } \\
\text { effectiven } \\
\text { ess }\end{array}$ & $\begin{array}{l}\text { Qu } \\
\text { alit } \\
\text { y }\end{array}$ \\
\hline Eigen Values & 8.97 & 2.892 & 2.149 & $\begin{array}{l}1.00 \\
1\end{array}$ \\
\hline Percentage of variance & $\begin{array}{l}42.71 \\
6\end{array}$ & 13.774 & 10.233 & $\begin{array}{l}4.76 \\
9\end{array}$ \\
\hline Cumulative percentage & $\begin{array}{l}42.71 \\
6\end{array}$ & 56.49 & 66.723 & $\begin{array}{l}71.4 \\
92\end{array}$ \\
\hline
\end{tabular}

Extraction Method: Principal Component Analysis. Rotation Method: Varimax with Kaiser Normalization. a. Rotation converged in 22 iterations.

\section{Correlation Analysis}

In this study, there were three objectives, that is whether project success (DV) correlated with each of the two independent variables (IVs) and whether the two IVs were correlated. The IVs were project implementation (Implementation) and risk management practices (Risk). The three variables were correlated at the bivariate level using Pearson's linear correlation coefficient because all the variables were numerical. This resulted in generating the correlation matrix in Table 7.

\section{Project Implementation and Risk Management Practices}

Results in Table 7 indicate that there was a positive linear correlation of $.271^{* *}$ at a $1 \%$ level of significance between project implementation and risk management practices. This implies that an improvement in project implementation leads to an improvement in risk management practices whereas a poor project implementation means poor risk management practices.

\section{Risk Management Practices and Project Success}

Results in Table 7 indicate that there was a positive linear correlation of $.292^{* *}$ at a $1 \%$ level of significance between risk management practices and project success. This implies that an improvement in risk management practices results in project success whereas poor risk management practices result in project failure.

\section{Project Implementation and Project Success}

Results in Table 7 indicate that there was a positive linear correlation of $.367^{* *}$ at $1 \%$ level of significance between project implementation and project success. This implies that an improvement in project implementation results in project success whereas a poor project implementation results in project failure 
East African Journal of Business and Economics, Volume 3, Issue 1, 2021

Article DOI: https://doi.org/10.37284/eajbe.3.1.296

Table 7: Correlation Analysis

\begin{tabular}{|c|c|c|c|c|c|c|c|c|c|c|c|c|c|c|}
\hline & 1 & 2 & 3 & 4 & 5 & 6 & 7 & 8 & 9 & 10 & 11 & 12 & 13 & 14 \\
\hline $\begin{array}{l}\text { P. implementation } \\
\text { (1) }\end{array}$ & 1 & & & & & & & & & & & & & \\
\hline Planning (2) & $\begin{array}{l}.485 * \\
*\end{array}$ & 1 & & & & & & & & & & & & \\
\hline Operation (3) & $\begin{array}{l}.484 * \\
*\end{array}$ & $\begin{array}{l}.329 * \\
*\end{array}$ & 1 & & & & & & & & & & & \\
\hline Control (4) & $\begin{array}{l}.528 * \\
*\end{array}$ & $\begin{array}{l}.320 * \\
*\end{array}$ & $\begin{array}{l}.311^{*} \\
*\end{array}$ & 1 & & & & & & & & & & \\
\hline $\begin{array}{l}\text { Risk Management } \\
\text { (5) }\end{array}$ & $\begin{array}{l}.271 * \\
*\end{array}$ & $\begin{array}{l}.078 * \\
*\end{array}$ & $\begin{array}{l}.176^{*} \\
*\end{array}$ & $\begin{array}{l}.313^{*} \\
*\end{array}$ & 1 & & & & & & & & & \\
\hline Identification (6) & $\begin{array}{l}.168 * \\
*\end{array}$ & $\begin{array}{l}.087 * \\
*\end{array}$ & $\begin{array}{l}.086 * \\
*\end{array}$ & $\begin{array}{l}.215^{*} \\
*\end{array}$ & $\begin{array}{l}.334^{*} \\
*\end{array}$ & 1 & & & & & & & & \\
\hline Monitoring (7) & $\begin{array}{l}.175^{*} \\
*\end{array}$ & $\begin{array}{l}.156^{*} \\
*\end{array}$ & $\begin{array}{l}.124 * \\
*\end{array}$ & $\begin{array}{l}.221 * \\
*\end{array}$ & $\begin{array}{l}.501 * \\
*\end{array}$ & $\begin{array}{l}.132 * \\
*\end{array}$ & 1 & & & & & & & \\
\hline Assessment (8) & $\begin{array}{l}.183 * \\
*\end{array}$ & $\begin{array}{l}.367 * \\
*\end{array}$ & $\begin{array}{l}.147 * \\
*\end{array}$ & $\begin{array}{l}.215^{*} \\
*\end{array}$ & $\begin{array}{l}.517 * \\
*\end{array}$ & $\begin{array}{l}.090 * \\
*\end{array}$ & $\begin{array}{l}.438 * \\
*\end{array}$ & 1 & & & & & & \\
\hline Response (9) & $\begin{array}{l}.235 * \\
*\end{array}$ & $\begin{array}{l}.100 * \\
*\end{array}$ & $.123^{*}$ & $\begin{array}{l}.256 * \\
*\end{array}$ & $.515^{*}$ & $\begin{array}{l}.298 * \\
*\end{array}$ & $\begin{array}{l}.312 * \\
*\end{array}$ & $\begin{array}{l}.370 * \\
*\end{array}$ & 1 & & & & & \\
\hline Project success (10) & $\begin{array}{l}.367 * \\
*\end{array}$ & $\begin{array}{l}.245^{*} \\
*\end{array}$ & $\begin{array}{l}.141 * \\
*\end{array}$ & $\begin{array}{l}.404 * \\
*\end{array}$ & $\begin{array}{l}.292 * \\
*\end{array}$ & $\begin{array}{l}.235^{*} \\
*\end{array}$ & $\begin{array}{l}.185^{*} \\
*\end{array}$ & $\begin{array}{l}.196 * \\
*\end{array}$ & $\begin{array}{l}.247 * \\
*\end{array}$ & 1 & & & & \\
\hline Timeliness (11) & $\begin{array}{l}.256 * \\
*\end{array}$ & $\begin{array}{l}.169 * \\
*\end{array}$ & $\begin{array}{l}.146 * \\
*\end{array}$ & $\begin{array}{l}.306 * \\
*\end{array}$ & $.161^{*}$ & $\begin{array}{l}.148 * \\
*\end{array}$ & $\begin{array}{l}.026 * \\
*\end{array}$ & $\begin{array}{l}.049 * \\
*\end{array}$ & $\begin{array}{l}.173 * \\
*\end{array}$ & $\begin{array}{l}.486^{*} \\
*\end{array}$ & 1 & & & \\
\hline S. Satisfaction (12) & $\begin{array}{l}.348 * \\
*\end{array}$ & $\begin{array}{l}.197 * \\
*\end{array}$ & $\begin{array}{l}.144 * \\
*\end{array}$ & $\begin{array}{l}.414^{*} \\
*\end{array}$ & $\begin{array}{l}.280 * \\
*\end{array}$ & $\begin{array}{l}.256^{*} \\
*\end{array}$ & $\begin{array}{l}.154 * \\
*\end{array}$ & $\begin{array}{l}.146^{*} \\
*\end{array}$ & $\begin{array}{l}.262 * \\
*\end{array}$ & $\begin{array}{l}.490 * \\
*\end{array}$ & $\begin{array}{l}.360 * \\
*\end{array}$ & 1 & & \\
\hline $\begin{array}{l}\text { C. Effectiveness } \\
\text { (13) }\end{array}$ & $\begin{array}{l}.247 * \\
*\end{array}$ & $\begin{array}{l}.179 * \\
*\end{array}$ & $\begin{array}{l}.068 * \\
*\end{array}$ & $\begin{array}{l}.266^{*} \\
*\end{array}$ & $\begin{array}{l}.237 * \\
*\end{array}$ & $\begin{array}{l}.194 * \\
*\end{array}$ & $\begin{array}{l}.129 * \\
*\end{array}$ & $\begin{array}{l}.143 * \\
*\end{array}$ & $\begin{array}{l}.187 * \\
*\end{array}$ & $\begin{array}{l}.471 * \\
*\end{array}$ & $\begin{array}{l}.269 * \\
*\end{array}$ & $\begin{array}{l}.303^{*} \\
*\end{array}$ & 1 & \\
\hline Quality (14) & $\begin{array}{l}.110^{*} \\
*\end{array}$ & $\begin{array}{l}.038 * \\
*\end{array}$ & $\begin{array}{l}.375^{*} \\
*\end{array}$ & $\begin{array}{l}.132 * \\
*\end{array}$ & $\begin{array}{l}.088 * \\
*\end{array}$ & $\begin{array}{l}.332 * \\
*\end{array}$ & $\begin{array}{l}.098 * \\
*\end{array}$ & $\begin{array}{l}.104 * \\
*\end{array}$ & $\begin{array}{l}.347 * \\
*\end{array}$ & $\begin{array}{l}.353 * \\
*\end{array}$ & $\begin{array}{l}.142 * \\
*\end{array}$ & $\begin{array}{l}.131 * \\
*\end{array}$ & $\begin{array}{l}.187 * \\
*\end{array}$ & 1 \\
\hline
\end{tabular}

**. Correlation is significant at the 0.01 level (2-tailed) 


\section{Regression Analysis}

In this study, there were three objectives; that is, whether there was a relationship between project success (DV) and the two independent variables
(IVs) and whether the two IVs were related. The IVs were project implementation (Implementation) and risk management practices (Risk). The DV was regressed on both IVs (implementation and risk) as shown in Table 8.

Table 8: Regression Analysis

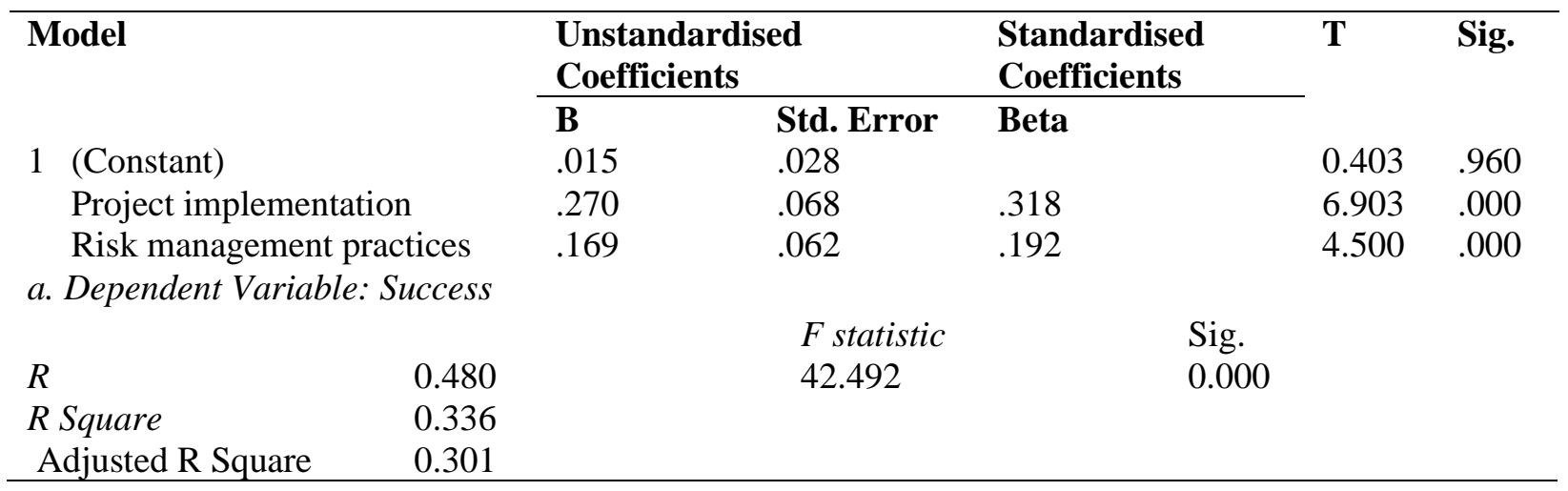

Results from Table 8 indicate that the model specified can predict project success at a $1 \%$ level of significance. Between risk management practices and project success, there exists a significant causal effect of .192. This means that a unit change in risk management practices brings about a 0.192 change in project success at a $1 \%$ level of significance. The table also indicates that there exists a positive causal effect between project implementation and project success of .318, which means that a unit change in project implementation brings about a 0.318 change in project success at a $1 \%$ level of significance. Risk management practices and project implementation predicted $30.1 \%$ of the variations in project success. However, project implementation is the most important predictor of project success according to the model and much emphasis should be put on it.

\section{CONCLUSIONS AND RECOMMENDATIONS}

Based on the results, it is noted that project implementation in terms of planning, operations and control affects risk management practices like identification, assessment, monitoring and response of projects. It is also concluded that risk management practices in terms of identification of risks, their assessment, monitoring and response affect project success in terms of timeliness, stakeholder satisfaction, cost-effectiveness and quality. It is further concluded from the model that project implementation in terms of planning of projects, their operations and control affect project success in terms of completion on time, meeting stakeholder satisfaction, being cost-effective and of quality.

The following recommendations are therefore suggested basing on this study;

(a) NGOs in Iganga Municipality need to lay emphasis on project implementation in terms of planning of projects, their operation and control. The NGOs should concentrate on proper project implementation to achieve their success.

(b) NGOs in Iganga Municipality need to be keen on risk management practices in terms of identifying risks, their assessment, monitoring and response.

(c) NGOs in Iganga Municipality need to monitor the performance of their projects closely to check on aspects of timeliness, stakeholder satisfaction, cost effectiveness and quality.

\section{REFERENCES}

Adams, J. R., \& Barnd, S. E. (1997). Behavioral implications of the project life cycle. In Cleland, D. I. \& King, W. R. (eds), Project Management Handbook (pp. 206-230). John Wiley \& Son. 
Ahmavaara, Y. \& Markkanen, T. (1958). The Unified Factor Model. The Finnish Foundation for Alcohol Studies.

Atkinson, R. (1999). Project management: cost, time and quality, two best guesses and a phenomenon, its time to accept other success criteria. International journal of project management, 17(6), 337-342.

Baccarini, D. (1999). The logical framework method for defining project success. Project management journal, 30(4), 25-32.

Belout, A. (1998). Effects of human resource management on project effectiveness and success: toward a new conceptual framework. International Journal of Project Management, 16(1), 21-26.

Bin. J., Heiser, D. R. Mangeni (2013), The eye diagram: A new perspective on the project life cycle. Journal of Education for Business, 80(1), $10-16$.

Blaskovics, B. (2014). Impact of leadership styles on project success-the case of a multinational company. Dynamic relationships management journal, 3(2), 21-36.

Bredillet, C. N. (2005). Reconciling Uncertainty and responsibility in the management of project. Project Management Journal, 36(3), 3-4.

Cooke-Davies, T. (2002). The "real" success factors on projects. International journal of project management, 20(3), 185-190.

Crawford, L., Pollack, J., \& England, D. (2006). Uncovering the trends in project management: Journal emphases over the last 10 years. International journal of project management, 24(2), 175-184.

Creswell, J. W. (2003). Research design, qualitative, quantitative and mixed methods approaches. ( $2^{\text {nd }}$ ed.). London: Sage.
Igwe, N. N., \& Ude, A. O. (2018). Project planning and implementation in Nigeria: Revisiting international best practices. European Scientific Journal, ESJ, 14(14), 152.

Jiang, B., \& Heiser, D. R. (2004). The eye diagram: A new perspective on the project life cycle. Journal of education for Business, 80(1), 10-16.

Jüttner, U., Peck, H., \& Christopher, M. (2003). Supply chain risk management: outlining an agenda for future research. International Journal of Logistics: Research and Applications, 6(4), 197-210.

Krajewski, L. J., \& Ritzman, L. P. (2005). Operations Management: Process and Value Chains. Upper Saddle River. NJ: Pearson Education.

Kumaraswamy, M. M. (2006). Accelerating construction industry development. Journal of Construction in Developing Countries.

Lorange, P. (2008). Thought leadership meets business: How business schools can become more successful. Cambridge University Press.

Marier - Bienvenue, T., Pellirin, R. \& Cassivi, L., (2017). Project Planning and control in Social and Solidarity Economy Organizations: A Literature Review. Procedia Computer Science 121 (2017) $692-698$.

Maylor, H. (2001). Beyond the Gantt chart: Project management moving on. European management journal, 19(1), 92-100.

Mumford, M. D., Mecca, J. T. \& Watts, L. L., (2015). Planning Process: Relevant Cognitive Operations. In M. D. Mumford \& M. R. Frese (Eds.). The Psychology of Planning in Organizations: Research and applications (pp. 9 -30). New York: Routledge. 
Munns, A. K., \& Bjeirmi, B. F. (1996). The role of project management in achieving project success. International journal of project management, 14(2), 81-87.

Plan international. (2014). The 2014 annual audit report of humanitarian, child-centred development organization. Plan International.

Prabhakar, G. P. (2005). An empirical study reflecting the importance of transformational leadership on project success across twentyeight nations. Project Management Journal, 36( 4), 53-60.

Shenhar, A. J., Dvir, D., Levy, O., \& Maltz, A. C. (2001). Project success: a multidimensional strategic concept. Long range planning, 34(6), 699-725.

Slevin, D. P., \& Pinto, J. K. (1987). Balancing strategy and tactics in project implementation. Sloan management review, 29( 1), 33-41.

Turner, J. R. (2004). Five necessary conditions for project success. International journal of project management, 5(22), 349-350.

UNNGOF. (2015). Uganda National Non Government Organization Forum Annual Report. Uganda National NGO Forum. 